\title{
THERAPEUTIC COMMUNICATION OF "SIRAMAN QOLBU" A DISCOURSE PERSPECTIVE
}

\author{
Syifa Fauzia Chairul ${ }^{1 *}$, Darsita Suparno ${ }^{2}$, Armawati Arbi ${ }^{3}$, Santje Inneke Iroth ${ }^{4}$ \\ ${ }^{1}$ Psychology, Universitas Indonesia, Depok, Indonesia \\ ${ }^{2}$ Translation, UIN Syarif Hidayatullah Jakarta, Indonesia \\ ${ }^{3}$ Islamic Broadcasting, UIN Syarif Hidayatullah Jakarta, Indonesia \\ ${ }^{4}$ Indonesian, Universitas Negeri Manado, Indonesia \\ syifafauzia@gmail.com*
}

\begin{abstract}
One of the phenomena of social crisis that occurs in society is marked by a trance. Unfortunately, this incident is often associated with mystical aspects. In fact, trance can be explained scientifically and it can be cured through therapeutic communication with religious nuances. This paper attempts to show that the stages of therapeutic communication and speech representation that is performed by Ustadz Danu in the healing process of a possessed person. The main purpose of this study is to develop an understanding of the stages of therapeutic communication and speech representation. This study used a descriptive qualitative approach taking a primary and secondary data sources by observing, documenting, and analysing. The result of this study indicate that: first, there are four stages religious therapeutic communication that can improve the mental peace of trance patients by counsellor through religious activities such as reading salawat, prayers, and dhikr. Second, after getting religious guidance, patients with mental disorders feel more inner peace than before, this can be seen from the patient's independence, and the way of communication of patients who began to gradually improve. Third, utterances of advice that show supporting factors in healing a possessed patient include adequate facilities, infrastructure, and family support
\end{abstract}

Keywords: Trance, Therapeutic communication, Speech representation

\section{Introduction}

The phenomenon of trance in the era of information technology is often exposed and discussed in multimedia. CNN Indonesia.com reported that on Thursday (19/11/2020), dozens of garment factory employees in Butuh village, Mojosongo District, Boyolali Regency, Central Java, experienced a trance. The factory management brought in the ustadz, doctors, and police to handle the case. Ustadz heals evil spirits, doctors to check the physical condition, and the 


\section{International Journal of Linguistics and Discourse Analytics}

Vol.2, No.2, March 2021

P-ISSN 2721-8899 E-ISSN 2721-8880

police secure the situation (Widodo, 2020, p. 1). Next, Travel.okezone.com reported on Saturday (4/02/2021) that a 16-year-old teenager was killed by a keris while dancing Rangda in Pemecutan Kaja, Denpasar, Bali. According to Balinese culture, Rangda is a dance that uses a mystical aura. The dancer can be in a trance (Rayputri, 2021, p. 1). The fact of trance is a phenomenon that often occurs in the community. According to Maramis, trance refers to a dissociation mechanism that can lead to multiple personalities and dissociative identity disorder (Maramis, 2010, p. 412). Handling someone in a trance is asking for help from religious experts, (Syarifah, 2019, pp. 108-120). This type of person has considered having a mental health disorder that indicates a loss of thoughts of self-identity and awareness of their environment. In some instances, the individual behaves as if he is controlled by another personality, supernatural power, or other force.

There are many kinds of social issues related to cultural elements in Indonesia, one of which is the practice of trance healing rituals, which involves many experts from various disciplines. General description of how to ritual and trance can be healed through prayer in Islam, although it has known that the healing of a possessed person exists a big difference with religious practice. Cultural background can shape the way people react and interact with each other for different reasons. Through the culture, people will have different values and beliefs, which have reflected by the language used and the way people communicate. Consequently, such diversities in the scope of metaphysical communication could be causes for cross-cultural communication, breakdowns among the human ability to communicate to other humans but also they can interact to magical powers, such as jinn, demons, (Sudarsih, 2020, p. 7). During the previous decades, transcendental communication term is a relative field of communication recently known in the field of communication science studies. Communication requires other knowledge, so it becomes multidisciplinary. It has developed through support from other sciences. Many realities of communication which must be studied cooperatively between communication science and science others, such as sociology, linguistics, anthropology, psychology, biology, and religious sciences.

The study of transcendental communication is a form of communication that is discussed minimally, in the discipline of communication, because of its abstract and transcendent nature. However, it is precisely this form of communication that is most important for humans with disorders to get treatment. Therapeutic language communication across borders can deal with metaphysical causes. Several scholars dedicate their study to the therapeutic analysis of communication with people with behavioral disorders. The act of treating someone who is in a trance has carried by someone who treats out with words, sentences that can produce a healing effect as (Yoshikawa et al., 2019, pp. 1-29) studied people with persistent pain due to various cultures and languages (abbreviated as CALD) people experience significant health problems. In the other hand, others conducted studies human behavior has been examined by scholars from 


\section{International Journal of Linguistics and Discourse Analytics}

Vol.2, No.2, March 2021

P-ISSN 2721-8899 E-ISSN 2721-8880

evolutionary psychology viewed. These disciplines have advanced the understanding of why humans suffer from psychological distress and mental illness. The theory of evolution has been used by assessing why humans are psychologically willing to cure other people's ills by focusing on the regulation of the interpersonal emotions that shape the way humans heal and comfort one another when under psychosocial stress. It happens because of emotion, empathy, and selfregulation. However, the claim the phenomenon of trance or mental disorder whether operate under some universal psychology norms or dedicated by a set of sociocultural, linguistics anthropology principles has been highly controversial. For instance, (Fachner \& Rittner, 2011, pp. 235-256) in their study of the ethno therapy, music and trance concluded that the sound of music can hint at shared belief systems and symbols chanted regularly can be used because the sound can stimulate mental activation back to normal so that the healing potential is proper. In brief, reaction to the sound of music seems to be more determined by the person's susceptibility to hypnosis, which can directly affect consciousness to recover.

In connection with the realization of a dialogue between a people who is tranced with a person who can treat, it gives evidence of communication between the astral beings that present in the patient's body. To remove the astral figure in the patient's body, the process of expulsion is carried out using the recitation of the Quran. There are certain aspects that were said by the patient when the process of expulsion of the astral was carried out. From this particular utterance or speech act, there is a universal aspect of therapeutic communication. Therefore, based on the therapeutic communication, this paper observes the al Quran verses and prayer therapy in the realizations of the healing of people who are physically sick, health mental disorder because often tranced, hallucination by many people in Indonesia. This study attempts to find answers to the following question: a) What are the stages of therapeutic communication carried out by ustadz Danu in the healing process of patients suffering from trance?, b) How the representation of ustadz Danu's utterance in therapeutic communication in the healing process of patients suffering from trance?

This study observes the stages of therapeutic communication carried out by ustadz Danu in the healing process of patients suffering from trance. It is hoped to facilitate the intercultural communication between the two target communities as it seeks to provide communication that has planned consciously, aims and activities are focused on healing the patient. Therapeutic communication has carried out by people face to face which allows each participant to capture the reactions of others directly, both verbally and nonverbally. This medical situation can be used by health law designers to pay attention to the possibility of diversity in traditional medicine methods and cultural conversations in the field of medicine, treatment, and medicine that draws on empirically hereditary experiences and skills that can be accounted for and applied under prevailing norms in society. This study is also hope to lay a better theoretical approach of the specify and/ or universality of critical discourse analysis to understand the series of speech 


\section{International Journal of Linguistics and Discourse Analytics}

Vol.2, No.2, March 2021

P-ISSN 2721-8899 E-ISSN 2721-8880

through semantic interpretation related to understanding what has said from what is done and directed to the problem of functional use of language

\section{Methods}

The writers uses the qualitative approach. According to (Creswell, 2009, pp. 145-147), the qualitative method is a research procedure that produces descriptive data in the form of oral and written words that have been observed by the writers from the behavior of the people has observed. In this case, the observation object is the therapeutic communication behavior carried out by Ustadz Danu to his client. The research strategy used Norman Fairclough's discourse analysis, (Fairclough, 1995, pp. 85-130). The research dimensions include: 1) texts that are analyzed linguistically through vocabulary, semantics, sentence structure, relationships between words in sentences that express one meaning. All elements of the text are analyzed to see several problems such as a) ideational, namely certain representations to be conveyed in the text, usually containing certain ideologies, b) relations refer to the construction of relationships between clients and counselors. The relationship is used to determine the text conveyed is open, closed, formal, or informal, c) Identity refers to the constitution of the identity of the client and counselor, as well as how personal and identity are displayed. The text requires semiotic analysis because there are sound effects, images or photos, and the organization of visual elements in the text. The text that was used as the object was Siraman Qalbu. 2) discourse practice is related to the process of producing and consuming text. Texts are produced by people specifically from repetitive routines and patterns of activity. The procession of consuming text is more personal, while the process of consuming text in a social context is collective. Further, the distribution of text depends on, such as: the type of pattern, text, the nature of the situation related to it (Fairclough, 1995, p. 100. 134-135). Text production has done by making a transcription of the MNC TV program "Siraman Qalbu" treatment for mental disorders or trance for three broadcasts. 3) socio-cultural practices are related to contexts that are outside the text as situations, institutional practices, and their relationship with society and culture.

Data in this study were collected from MNC TV "Siraman Qalbu" by focusing on the use of language in the dialogue between clients and Ustadz Danu during the healing process that has gathered in some steps as follow: a) every episode is watched repeatedly for three times to get deep understand the content of the therapeutic communication; b) identifying the title of every chapter in the whole episode; c) marking the text, especially sentences, phrases, words, which contain therapeutic verbal meaning and marking the photo action that trance person or mental disorder, d) categorizing these verbal symbol and non-verbal symbols into appropriate meaning. Data that have been collected, first are classified into the themes. Data analysis was carried out by analyze text's Fairclough using three stages, namely: macrostructure, superstructure, and microstructure. Text analysis used Saussure semantic analysis. It is used for parole analysis, 
International Journal of Linguistics and Discourse Analytics

Vol.2, No.2, March 2021

P-ISSN 2721-8899 E-ISSN 2721-8880

langue, syntagmatic and paradigmatic, markers, and markers. Therapeutic communication analysis uses Corey's theory. These three theories are assumed to be related to each other for the following reason: the text is a device composed of macrostructure, superstructure, and microstructure, which combine illustrate language events, communication events, which all relate to concepts and references outside of language.

\section{Findings and Discussion}

Therapeutic communication in this discussion is considered as a form of interpersonal communication that is specifically intended for the recovery process or physical therapy and mental disorders. Recovery action is characterized by an exchange of behavior, feelings, thoughts, and experiences. Healing events that are broadcast in each "Siraman Qalbu" theme on MNC TV can also be obtained on social media Youtube. Through Youtube, the theme that becomes the object is chosen randomly. The chosen theme was analyzed using Norman Fairclough's critical discourse analysis method.

The analysis starts with the following stages: discussion through critical discourse analysis framework:

Tabel 1. "Sore Throat"

\begin{tabular}{|c|c|c|}
\hline $\begin{array}{l}\text { Discourse } \\
\text { structure }\end{array}$ & Element & Analysis result \\
\hline Macro structure & Theme/topic & "Sore throat, head, stomach ache" \\
\hline Superstructure & $\begin{array}{l}\text { Schematic } \\
\text { Scheme }\end{array}$ & $\begin{array}{l}\text { Summary: Siraman Qalbu MNC TV program explained } \\
\text { that a } 30 \text {-year-old housewife experienced a sore throat, } \\
\text { stomach, back, shortness of breath, leg pain for } 2 \text { years } \\
\text { Lead: She explains about the illness to TV audiences that } \\
\text { the disease occurs because of doing weird practices. } \\
\text { Story, content and ending: A wife who is often angry } \\
\text { with her husband will suffer physical pain. The physical } \\
\text { pain has been caused by her husband that is doing weird } \\
\text { practices. Without realizing it, the impact of the magic } \\
\text { practices caused illness in his wife. The healing of the } \\
\text { disease can only occur if the husband and wife forgive } \\
\text { each other. }\end{array}$ \\
\hline \multirow[t]{2}{*}{ Micro structure 1} & Semantics & \\
\hline & Background & $\begin{array}{l}\text { The background elements discuss the physical pain that } \\
\text { has been experienced by the woman for two years. Saya } \\
\text { Viarina dari Brebes; panggilannya Via? Panggilan, } \\
\text { Rina. Ooo Rina }\end{array}$ \\
\hline
\end{tabular}

Micro structure 1 Detail The detailed element discusses the existence of 81 
International Journal of Linguistics and Discourse Analytics

Vol.2, No.2, March 2021

P-ISSN 2721-8899 E-ISSN 2721-8880

Micro structure 1 Intention

Micro structure 1 Presupposition nominalization supernatural attacks from husbands to wives. The attack occurred because the husband was hurt, and his wife often scolded him.

The element of the intention to explain explicitly that the husband must forgive his wife

The presupposition element explains that magic in the wife's body has taken out by the wife apologizing to her husband.

Micro structure 2 Syntax

Sentence form

Micro structure 2 Coherence

Micro structure 2 Pronounce

Micro structure 3 Stylistics: lexicon (diction)

Lexicon
(1) Apakah Bapak memiliki amalan tertentu ya? (2) Saya memiliki amalan waktu saya masih sekolah. (3) Perasaan jengkel kepada istri menjadi sebab ilmu itu menyerang kepada istri bapak. (4) Ia sakit sekarang. Sentences (1-4) have been identified as a one-paragraph opinion sentence. The main idea lies at the end of the paragraph. This paragraph begins with explanatory sentences, which can be in the form of facts, pieces of evidence, which has concluded into one inductive sentence at the end of the paragraph.

Utterance form: (5) Mas Nur sebagai suami kalau istri ngomel mau memaafkan semanta-mata karena Allah Ta'ala, mau? (6) Iya mau. Saya mau memaafkan kekurangan istri saya. Speeches (5-6) are identified as sentences that have good coherence because they contain messages. Besides, there are repetitive elements of language, indicating that this discourse forms have a unified message.

Utterance form: Kalau bisa, Mas Nur mau mengeluarkan ilmu dari tubuh mba Rina. Apakah mas Nur mau melakukannya? Iya tapi saya tidak bisa. Mba Rina, saya ingin mba Rina meminta maaf kepada mas Nur karena itu suami ibu. This utterance has been identified as a sentence that uses the third person pronoun self (Rina, Nur), the first person singular (I), a term of address word (mother).

Utterance form: (6) Apakah mba Rina memanggil kepada suami dengan panggilan, yayang, mas, bebeb atau pak? (7) Saya memanggil suami pak, bapak.

In sentence (6) there is a choice of words that are 


\section{International Journal of Linguistics and Discourse Analytics}

Vol.2, No.2, March 2021

P-ISSN 2721-8899 E-ISSN 2721-8880

(diction) synonymous with yayang, mas, bebeb, bapak or pak to address someone familiar or loved.

In sentence (7), there is a lexicon explaining the word pak, bapak is a polite form of Mba Rina as a wife to her husband by not mentioning names.

Micro structure 4 Rhetorical: Graphic elements describe Rina's happy face after graphic recovering from illness. Pak Nur feels glad to see that his wife is healthy. This situation can be seen through MNS TV or Youtub channel.

Metaphor: Metaphorical elements explain many social issues. expression Indonesian society has mystical or supra-rational knowledge that emerges through social behavior or empirical evidence.

Meso structure Texts The setting refers to the MNC TV program "Siraman production Qalbu" as program production, client or patient has identified as the part of society that consumes the TV program production.

Attitude has been shown by the individual awareness of $\mathrm{Bu}$ Rina and Pak Nur to determine real actions to cure mystical diseases.

Bu Rina and Pak Nur's actions consulted the Siraman Qalbu event intending to cure bu Rina illness.

Meso structure Consume text Utterance form: (8) Pak maafkan saya jika selama ini sering merasa jengkel kepada bapak.

(9) Bagaimana rasa sakitnya bu Rina. (9) Agak mendingan.

MNC TV program "Siraman Qalbu" is identified as an economic activity. This activity is a product in physical form or construction of services values, which can be consumed by the wider community. Besides, there is a consumption of time that is generated and provides added value such as convenience, entertainment, pleasure, or health information or solving problems faced by consumers.

In Table 1, it is described a client with a sore throat who came to the "Siraman Qalbu" for medicinal purposes. The event was chaired by the host Irfan Hakim, and counselor, Ustaz Danu. The event was attended by 60 people from the majelis taklim association members. Mrs. Rina was asked to present her sick complaint in front of the association members. The arrival of the client was warmly welcomed by the audience while greeting Assalamu'alaikum Warahmatullahi 
International Journal of Linguistics and Discourse Analytics

Vol.2, No.2, March 2021

P-ISSN 2721-8899 E-ISSN 2721-8880

Wabarakaatuh. Utterance no (1) Saya Viarina dari Brebes. (2) Panggilannya Via? (3) Panggilan, Rina. (4) Ooo Rina. On utterance (1) Saya Viarani dari Brebes, identified as a single sentence that has the predicate or verb $(\mathrm{V})$ omitted, namely bernama. The sentence should be: Saya Viarani berasal dari Brebes. Saya as Subject, berasal a Verb, dari Brebes (prepositional phrase) this way is viewed based on the syntactic function (subject, predicate, object, complement).

When describing a pain her the physic, there are utterance, namely: (5) Sakitnya dari tenggorokan, dada, perut ke paha, kaki. (6) Sakitnya muter-muter gitu! (7) Sakit muter-muter itu kampanye apa gimana? The sentence (6-7) is categorized as implicature. Sakitnya muter-muter gitu the utterance semantically, means 'I had a sore throat, chest pain again, then I felt pain in my leg repeatedly.' The meaning of this utterance has understood by the speaker. In this context, the client, the audience present, and Ustadz Danu as a counselor. In short, In short, dialogue (6-7) contains implicatures that involve interpretations that occur indirectly. The dialogue contains implicature or message that have already known by the speaker, and therefore do not need to be expressed explicitly. This implicature is hidden so that what is implied does not appear too clearly. This communication event is appropriate with the concept of implicature (Grice, 1975, p. 43). In sum, implicature is speech that implies something different from what has spoken. That something "different" is the speaker's intention which was not been stated explicitly. In other words, implicatures are hidden intentions, desires, or expressions of the day. In the context of sentence (6), when Rina complained about her pain, Ustad Danu as a therapist could understood Rina's message. Speech (7) is an utterance is pronounced seemingly different from what is meant.

The flow of treatment for client disease begins with the explanation of pain in the throat, backache, chest, thighs, and feet for one year and a half. After observing the client's behavior towards her husband, it turned out that Mrs. Rina was often angry with her husband. Besides, he had a mystical experience that he had obtained from his father. The counselor also tries to explain the causes of the disease and how to deal with the disease. The healing of the disease began when Mrs. Rina has advised holding her husband's hand while apologizing for her mistake. She was often angry with her husband. Besides that, Ustadz Danu also prayed for him to get well soon. The medical practice was closed after the client apologized to her husband, and her husband forgave Mrs. Rina, his wife. With patience and sincerity from her husband, Mrs. Rina's feels well. Then Ustaz Danu asked for forgiveness and protection from Allah.

In the microstructure, this study focuses on semantic analysis, sentence structure, stylistics, and rhetoric. The four elements that have been observed by the writers included setting, intention, sentence pattern, coherence, pronouns, vocabulary, graphics, and the use of words in the medical dialogue. In terms of semantics, the expressions in the medical conversation show three aspects of namely: faith, sharia, and Islamic morals. In terms of syntax, 


\section{International Journal of Linguistics and Discourse Analytics}

Vol.2, No.2, March 2021

P-ISSN 2721-8899 E-ISSN 2721-8880

the speakers use many elements of the perfect sentence according to the rules. Consists of Subject, Predicate, Object, and information such as "Saya sudah merasakan sakit kaki selama enam bulan," it is identified as ( $\mathrm{S}+\mathrm{P}+$ Keterangan). Another example: "Hal ini terjadi karena Mba Nur sering ngomelin Mas Nur di rumah", it is identified as $(\mathrm{S}+\mathrm{P}+$ Conjunction+ $\mathrm{S}+\mathrm{P}+\mathrm{O}+\mathrm{K})$.

Stylistically, the description of conversation about Mrs. Rina's healing on the choice of words used in the treatment dialogue. For example: Mba Rina memanggil apa kepada suami? Apakah memangil dia dengan sapaan yayang, mas, bebeb, pak atau bapak? This sentence shows the choice of words in a non-formal variety, namely mas, bebeb, and yayang, while the choice of words Pak or Bapak is considered a formal word choice. Another sentence Mau nggak kamu memaafkan, Mas Nur tidak sadar ya, ilmunya menyerang orang lain? This sentence shows the choice of words in a non-formal variety, such as the word nggak with the meaning 'no.' Observation rhetorically focuses on metaphorical elements. Observations have shown in the language style (figure of speech) used by the client and counselor. There are several language style are used in the dialog, such as satire for example: Makanya kalau amalan yang amalan yang bener jangan sembarangan di kasih orang. An affirmation of the style, for example: Kalau tidak atas izin Allah SWT kita tidak mengerti bahwasanya mba Nur diserang oleh ilmu yang dimiliki suaminya. Contradictory style, for example: Penyakit ini tidak bisa diobati dengan cara dipijit, kalau dipijit ilmunya akan menyerang secara tidak terkendali.

The results of the data analysis as above show the specific behavior of a physically ill client caused by his behavior. To know this situation, Ustadz Danu needs a careful observation of the behavior of clients who come to his client. For clients who have been treated, the counselor asked them to change their old behavior with new ones that are positive and spiritual. The client has asked to state in concrete ways through speech, as well as the types of behavior he wants to change. Therefore, there are three findings obtained from critical discourse analysis as listed in table 1, namely: this Siraman Qalbu event has succeeded in fulfilling the client's goal, namely recovering from physical and psychological illness, Ustadz Danu as a counselor is willing to help clients to achieve goals to be healthy, willing active and empathic listening to client difficulties, using simple and clear language, helps translate client confusion into concrete goals that can be achieved after treatment.

Based on Islamic psychological characteristics, counselor performed the treatment of pain in Rina's throat, chest, and shortness of breath through prayer communication. For treatment, several stages have carried out, namely: focusing attention on behavior, pain, social relations, especially to the husband that appears specifically, accuracy in praying to Allah Ta'ala for the description of treatment goals. Both counselor and clients try to be quiet and keep their eyes close when the worship is taking place. They understand that prayers are usually a quiet time to praise God. They are encouraged to accept each other, forgive others' mistakes, and 


\section{International Journal of Linguistics and Discourse Analytics}

Vol.2, No.2, March 2021

P-ISSN 2721-8899 E-ISSN 2721-8880

sincerely pray. Prayer is a time when the whole family or one member share their worries, thought, or thanks. After praying, the client named Rina felt healed from her illness. In short, there were five stages carried out by counselor in conducting therapeutic communication to cure Mrs. Rina's sick. Prayers guided by him to clients show a spiritual dimension. He pays attention to the pattern of the nurse-patient relationship (in this case, ustadz Danu and client). Prayer is holistic, includes asking for the aspects of safety, exploring the causes, and improving the quality of daily behavior both to humans and God. He teaches ways that can be used to behave patiently. A person can express anger that can be accepted by all parties without being destructive (assertive). These five stages are compatible with the therapeutic communication process (Corey, 2017, p. 441). Results of the analysis show that the treatment performed by counselor is a type of psychotherapy treatment, especially Islamic psychotherapy. He argues that health is related to physical and psychological aspects; all diseases suffered by humans are the result of human behavior itself; disrespectful behavior can have an impact on mental and physical illness in humans. According to counselor, in the spiritual dimension, the therapeutic communication that it applies places all problems or problems (including those experienced by clients) as something that brings benefits and goodness, as long as the intention is that problematics are a means of getting closer to Allah SWT

\section{Conclusion}

Based on critical discourse analysis focus on the research question a) the writer found five stages therapeutic communication, such as: (i) clients are given an opportunity to describe their problems, (ii) explains the client's family background and ask them to join the healing process, (iii) explains the causes of her illness, (iv) Then, he says a prayer before healing the disease, (v) at the end of each solution the therapist provides encouragement, and suggests what clients might do for the future. Referring to the representation of Ustaz Danu's utterance in therapeutic communication in the healing process of patients suffering from physical pain and mental health disorders the writers found 25 simple sentences, 8 complex sentences and four language representation, namely one type of implicature found in the informal conversation. As the suggestions, for the next researcher, it is expected to analyze of implicature in others subject such as daily communication at doctor patient therapeutic, therapist client, communication on social media. The result of this study is also expected to give additional information for discourse study, related to psychology, communication, linguistics, pragmatics, linguistics anthropology study and the other studies, which has analysis in conversation such as television program, and radio broadcast 
International Journal of Linguistics and Discourse Analytics

Vol.2, No.2, March 2021

P-ISSN 2721-8899 E-ISSN 2721-8880

\section{Acknowledgement}

This research was supported by Islamic Broadcasting Communications Department UIN Syarif Hidayatullah Jakarta and Faculty of Psychology Universitas Indonesia

\section{References}

[1] Corey, G. (2007). Theory and Practice of Counseling and PScychotherapy (Teori dan Praktik Konseling dan Psikoterapi ) Diterjemahkan oleh E Koeswara (2nd ed.). Reika Aditama.

[2] Corey, G. (2017). Theory and Practice of Counseling and Psychotherapy (10th ed.). Cenveo. www.cengage.com/mindtap

[3] Creswell, J. W. (2009). Research Design Qualitative Quantiative and Mixed Methods Approaches Third Edition (Third Edition). SAGE Publication, Inc.

[4] Fachner, J., \& Rittner, S. (2011). Ethno Therapy, Music and Trance: An EEG Investigation into a Sound-Trance Induction. In States of Consciousness Experimental Insights into Meditation, Waking, Sleep and Dreams (pp. 235-256). Springer. www.springer.com

[5] Fairclough, N. (1995). Critical Discourse Analysis: The Critical Study of Language. Longman.

[6] Maramis, W. F. (2010). Catatan Ilmu Kedokteran Jiwa. (2nd ed.). Universitas Airlangga Press.

[7] Sudarsih, S. (2020). Metaphysic Dimension in Labuhan Ceremony of Yogyakarta Palace. 202(E3S Web Conf.), 1-7. https://doi.org/10.1051/e3sconf/202020207051

[8] Syarifah. (2019). Fenomena Kesurupan Dalam Persepsi Psikolog Dan Peruqyah. Jurnal Studia Insania, 6(2), 108-120. https://doi.org/10.18592/jsi.v6i2.2208

[9] Widodo, T. (2020, November). Puluhan Karyawati Pabrik Garmen Tas di Boyolali Kesurupan. Jawa Pos Radar Solo. https://radarsolo.jawapos.com/read/2020/11/20/225766/puluhan-karyawati-pabrikgarmen-tas-di-boyolali-kesurupan

[10] Yoshikawa, K., Brady, B., \& Perry, M. A. (2019). Sociocultural factors influencing physiotherapy management in culturally and linguistically diverse people with persistent pain. Elsevier Ltd, 1-29. https://doi.org/10.1016/j.physio.2019.08.002 